\title{
STUDYING THE IMPACT OF FOURTEENTH FINANCE COMMISSION (FFC : 2015-20) RECOMMENDATIONS ON FISCAL DECENTRALISATION AND THE CONSEQUENT IMPACT ON SOCIAL SECTOR EXPENDITURE - A NATIONAL AND STATE-WISE ANALYSIS
}

\author{
Aditya Bihani
}

NMIMS University, Mumbai (Bsc Economics)

DOI: 10.46609/IJSSER.2020.v05i10.002 URL: https://doi.org/10.46609/IJSSER.2020.v05i10.002

\section{ABSTRACT}

This paper seeks to study the impacts of the recommendations of the Fourteenth Finance Commission (FFC) with respect to greater devolution of untied transfers from centre to states. This recommendation was made and carried on keeping in mind that the states should be granted greater flexibility with regards to expenditure. However whether the states have used this increased flexibility to enhance expenditure on social services is what will determine the success of the FFC recommendation. As the period of the FFC (2015-2020) draws to a close understanding whether the recommendation was a success or not is of importance.

Keywords: Centralisation, Fiscal Structure in India, Social Sector Expenditure, Fourteenth Finance Commission.

\section{Introduction and Literature Review}

In Feb 2015, the Indian economy set out on a path to enhance fiscal decentralisation. The Government of India (Modi regime) accepted the recommendations made by the Fourteenth Finance Commission (FFC) to increase the share of state governments in the central divisible pool of taxes by 10 percentage points. The objective of this move was to enhance decentralisation of the fiscal architecture and enable state to allocate funds to the sectors which they deemed to be priority sectors. The reforms were initiated in congruence with the the political rhetoric of the NDA government to strengthen 'cooperative and competitive federalism' in India. In several public statements after taking office in 2014, the Prime Minister had repeatedly stressed the pivotal role of State governments as 'drivers of transforming India , appealing to states to 'imbibe the spirit'of cooperative federalism.Thus, in rhetoric and in action, 


\section{International Journal of Social Science and Economic Research}

ISSN: $2455-8834$

Volume:05, Issue:10 "October 2020"

India in 2015, was firmly on the path towards putting in place a new decentralised fiscal architecture.

This effort to promote 'co-operative federalism 'provides an interesting case to investigate a key pivot in debates revolvingaround fiscal decentralisation, which is :'the potential trade-offs between expenditure efficiency and local accountability through greater decentralisation on the on hand and regional variation in social outcomes on the other'.This paper seeks to add on to current empirical analysis and understandings of these trade-offs by investigating whether these recommendations have indeed led to an increase in the flow of untied funds to the states and of as to whether the states have seen increased social sector expenditure/development on account of increased flexibility in the usage of funds.

India's federal architecture is widely recognised for having several centralising features embedded within it. Scholars have described India's federalism as 'quasi federal 'or 'holding together federalism '(Stepan 1999; Wheare 1964). This centralised federalism is particularly visible in the constitutionally mandated fiscal federal framework. The delegation of fiscal powers and responsibilities specified in the constitution reflects what Rao and Singh (2005) have characterised as a "centripetal bias with the Centre having "overwhelming and overriding" economic powers'.

From the perspective of the federal bargain, two critical changes stand out. First, the evolution of India's polity from single party dominance to a multi-party dominance with regional political parties, particularly from the 1990s onward playing a significant role in shaping national politics. Second, the shift in policy toward economic liberalisation that necessitated a move away from centralised planning toward greater economic autonomy for state governments. These shifts in India's political and economic landscape set the stage for a new phase in India's federalism (Mitra and Pehl 2010; Saez 2002; Singh and Verney 2003), with states claiming greater autonomy and attempting to renegotiate the dynamics of centre-state relations.

CSS and central government encroachment on state subjects have been a repeated source of tension between the centre and states. However, until the FFC recommendations, this tension had not resulted in any change in India's fiscal architecture. Rather than decentralising, India became far more centralised in its financing for social policy even as politics and the economy became more decentralised, which is a conundrum. Srinivasan and Wallack (2011) attempt to unpack this puzzle in their paper by arguing that India's economic and political structures have impeded collective action by states, making it difficult to bring fiscal concerns into the political federal bargain. This paper whoever does not extend its analysis to understanding the effects of the centralising/decentralising dynamic on social policy investment choices and ultimate outcomes 


\section{International Journal of Social Science and Economic Research}

ISSN: $2455-8834$

Volume:05, Issue:10 "October 2020"

as their paper took for granted that the decentralising dynamic will increase social policy investment. This paper seeks to question this implicit assumption made by them.

\section{Data and Methodology}

Data used has been sourced from the RBI handbook of Statistics, RBI e-states handbook, Finance accounts of states at the Auditor Comptroller General of India, State data from the Central Statistics Office database. The period we have considered for our analysis is broadly from 2010-11 to 2019-20.

However it is important to keep in mind that the period which we have used to draw conclusions and which should be used is from 2014-15 to 2017-18 with 2014-15 as the base year for comparison. This is because comparable state-level figures of transfers and expenditures prior to 2014-15 are not available from budgets. Till 2013-14, much of the grants under CSS were not routed through the state treasuries and were not captured in budgetary figures of the state. Thus 2014-15 is the only year in the Thirteenth Finance Commission period in which budgetary data on transfers and expenditures are comparable with the FFC years. Secondly we have not paid attention to the years 2018-19 and 2019-20 because the estimates obtained for these two years are revised and budget estimates respectively. Since such estimates are generally always much higher than the actual estimates for most states, it would not make sense to compare the same along with the other years.

The methodology used in the paper is a relatively simple one. We make use of varied visitations at the centre and state levels. Furthermore, we do a same disaggregated visual trend study for social sector expenditure for varied states. To give a better idea of the visuals, three data tables are included in the paper. Even though four years is good enough to get a broad idea of the changes of state and centre finance via visualisations, such a low number if years inhibits our ability to make use statistical tools to comment on the same. Thus a thorough statistical analysis is out of scope for this paper.

The way we have defined what constitutes tied and untied transfer is of crucial importance:

1) Untied Transfer from the centre :- (Share in Central Taxes + Non Plan Grants)

2) Tied Transfers :- (Grants from the Centre - Non Plan Grants)

It is important to note that even within the Plan Grants and CSS there are a few grants which have great flexibility and thus should technically fall under the ambit of untied grants, however the quantum of these are relatively minimal and thus our definitions as given above can be considered largely accurate indicators for the precise amount of ties and untied funds. 
International Journal of Social Science and Economic Research

ISSN: 2455-8834

Volume:05, Issue:10 "October 2020"

\section{Analysing the outcomes of the FFC recommendations and studying the results}

1) Change in net resources:

The initial stage of implementation of the FFC reforms took place in the 2015 budget with the union government increasing ta devolution to states from $32 \%$ to $42 \%$, which amounted to an increase of Rs 1.69 lakh crore (from Rs 3.37 lakh crore in 2014-15 to Rs 5.06 lakh crore in 2015$16)$.

As is evident from Figure 1 in the appendix on the right (y-axis is amount is crores), share of states in central transfer (tax devolution) shot up from 2014-15 which is when the FFC recommendation started being implemented. In other words, the pool of untied funds to states increased to a great extent.

As a proportion of GDP as well, tax devolution increase from $2.7 \%$ to $3.7 \%$ from 2014-15 to 2015-16. This ration has increased further to more than 4\% as of 2018-19 and 2019-20 (however data for 2019-20 are budget estimates and cannot be trusted since revised estimates and actual estimates tend to always be lower than budget estimates). The trend is evident in the Figure $\mathbf{2}$ in the appendix.

To accommodate this increase, given the limited fiscal space available with the Union government, the devolution was accompanied by a reduction in conditional (tied) grants to states, particularly a cut in CSSs. Conditional (tied) central assistance to state plans including for CSSs, decreased from Rs. 2.59 lakh cr in 2014-15 to Rs. 2.12lakhcrore in 2015-16. This trend is evident in the Figure 3 in the appendix. Even though the figures shows a big spike in tied transfers for 2018-19 and 2019-20, it is important to keep in mind that these are revised and budget estimates. Actual estimates are almost lower than such revised and budget estimates. The trend for tied transfer as a \% of GDP from centre to all states shows how it reduced sharply post the 2015 budget and has remained so only to shoot up in 2018-19 and 2019-20 which as mentioned are not actual estimates and hence should not be considered accurate.

Despite this decrease in grants, analysis of the aggregate net transfers (devolution and grants) from the Union to states increased, albeit marginally, from 5.38\% of GDP in 2014-15 to 6.08\% in 2015-16. This trend continued till a small drop in 2017-18 ; see Figure 4 in the appendix.

2) Composition of transfers :

While the overall increase of overall transfers from the centre was modest, the FFC never intended to this, but simply intended to change the composition of transfers. The FFC aimed to 
increase the amount of untied (unconditional) funds flowing to states at the expense of tied (conditional) funds. The Figure 5 in the appendix shows how's the share of untied funds in the total pool of funds spiked up and that of tied funds fell.

As is seen above the share of untied transfersincreased from $61 \%$ to $74 \%$ while the proportion of conditional tied transfers (primarily through scheme grants) decreased from $39 \%$ to $26 \%$ between 2014-15 and 2015-16. This change in the mode of transfers is also reflected in State budgets. An analysis of state budgets suggests that as expected, most states (except Madhya Pradesh and Jharkhand) did see a reduction in tied transfers as a proportion of their GSDP when compared to the 2014-15 values. At the same time all the states saw a spike in the untied funds as a \% of GSDP which had remained relatively high since 2015-16. The same is seen in the Figure 6(a) and 6(b) below. The values for 2018-19 and 2019-20 is not included because the actual estimates for the same is not available. Furthermore, the states studied for this analysis do not include special category states like Assam and north eastern states since they follow a different economics structure.

Figure 6(a) :

\section{Tied Funds as a \% of GSDP for major states in India :}

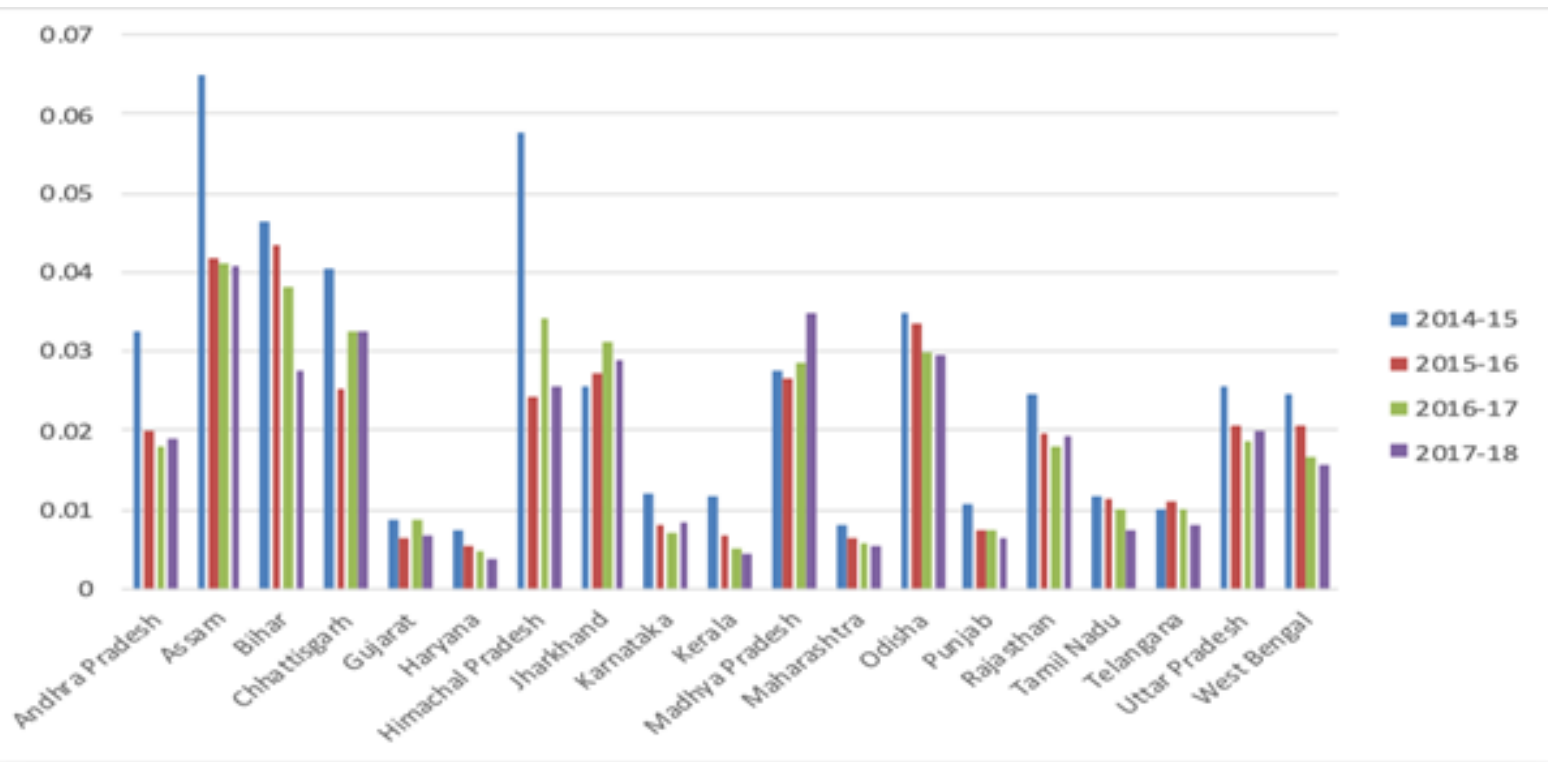

\section{Source - Finance accounts of States; Auditor Comptroller General of India States Data}




\section{International Journal of Social Science and Economic Research}

ISSN: 2455-8834

Volume:05, Issue:10 "October 2020"

Figure 6(b) :

\section{Untied Funds as a \% of GSDP for major states in India :}

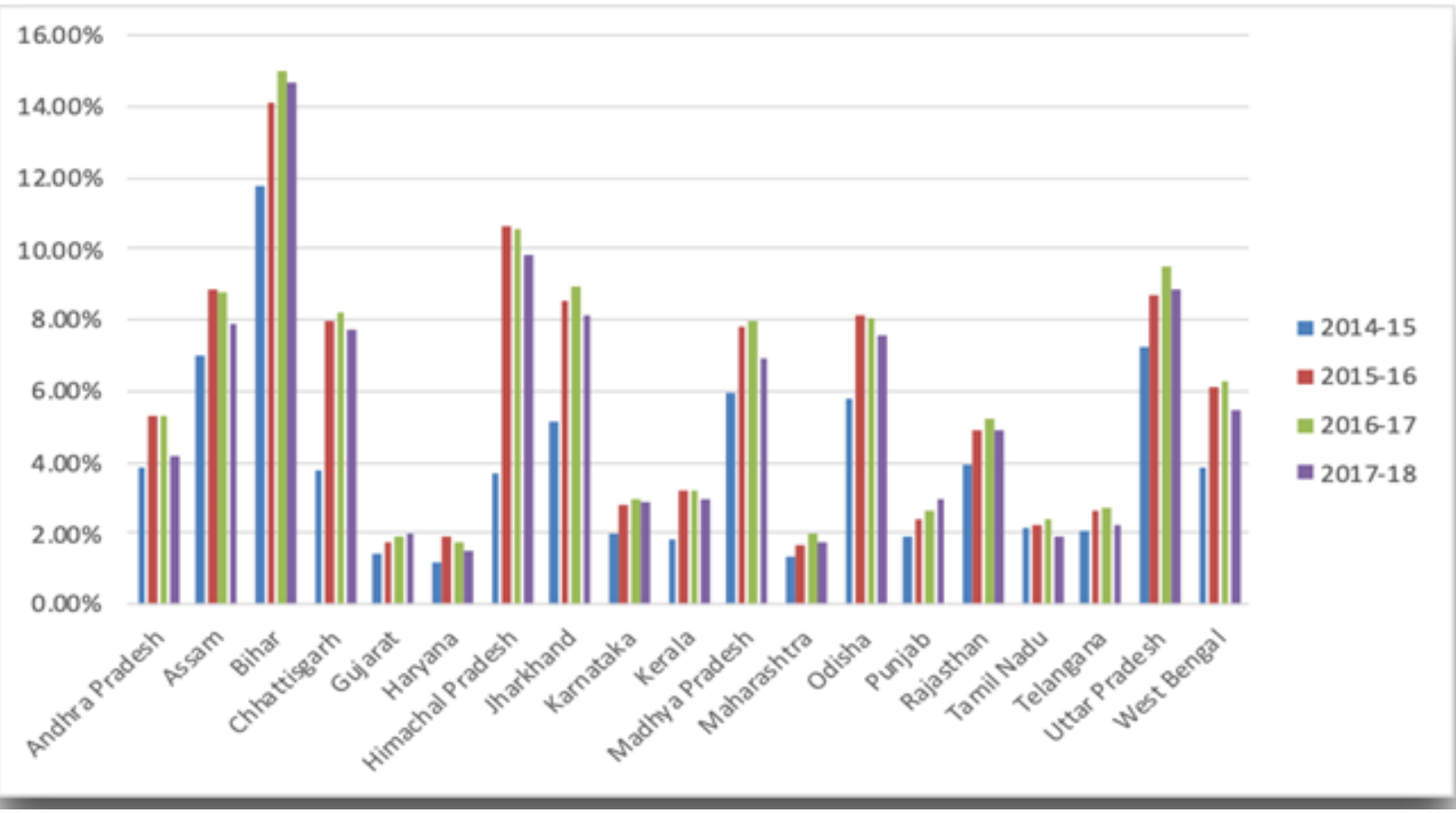

\section{Source - Finance accounts of States; Auditor Comptroller General of India States Data}

This simple analysis does however pose a small problem however because the base year of comparison which is 2014-15 could have shown unusually high or low values. Thus, as a solution to this conundrum, Choudhury, Mohanty, and Dubey (2018), compared the 2015-16 share of plan transfers as a proportion of GSDP with the average share of plan transfers during the Thirteenth FC period (2011-2015) and ran statistical and hypothesis tests. Their analysis found that even after increasing the number of years, the decline in plan transfers is significant.

3) Social sector expenditures :

The previous two sections make is clear that the FFC recommendations did result in an increase in untied funds and a consequent reduction in tied funds flowing from the centre to the states. Thus, greater flexibility in terms of the usage of central fund transfers should have helped states spend more on social service expenditures. This section therefore analyses whether the states used their increased flexibility to augment social sector expenditure or preferred to maintain the status quo. As will be observed from the analysis that follows, states preferred to maintain a status quo. The Figure 7(a) below shows how states except West Bengal, Uttar Pradesh, Madhya 
Pradesh andChattisgarh either ended up reducing social sector expenditure as a \% of GSDP or maintained status quo. This trend of increased flexibility but reduced expenditure becomes evenmore apparent in Table 1 and Table 2 as given below after the figures 7(a) and 7(b).

A deeper analysis within social service expenditure for the major states that we have considered for the analysis shows that for the varied sectors the expenditure remained constant on a whole (with the exception of the Urban Development and Housing sectors). This is evident from the Figure 7(b) as shown below.

\section{Figure 7(a):}

Social Sector Expenditure as a \% of GSDP for major states in India :

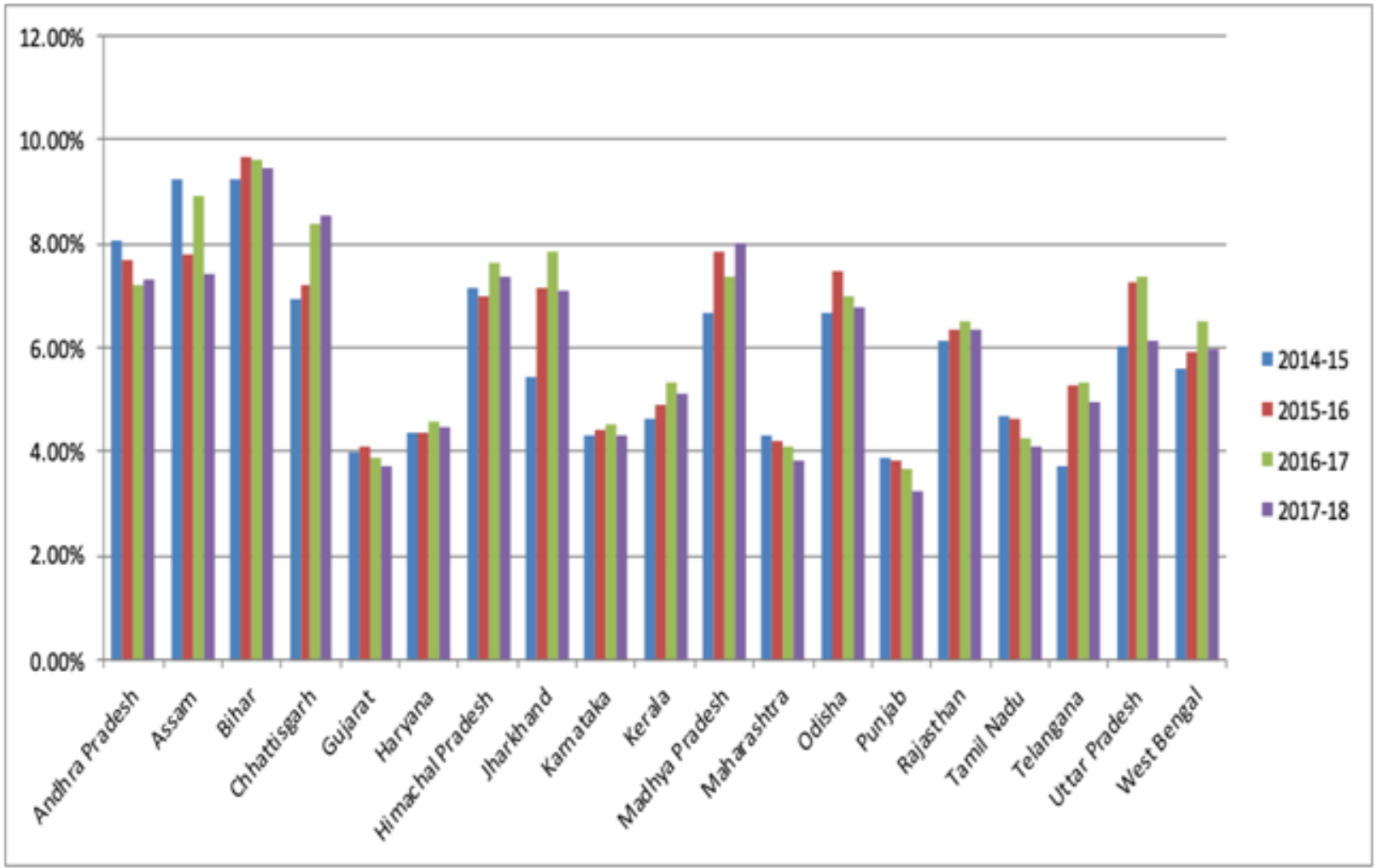

Figure 7(b): 
International Journal of Social Science and Economic Research

ISSN: 2455-8834

Volume:05, Issue:10 "October 2020"

Sector wise Expenditure as a \% of GSDP for all states in India :

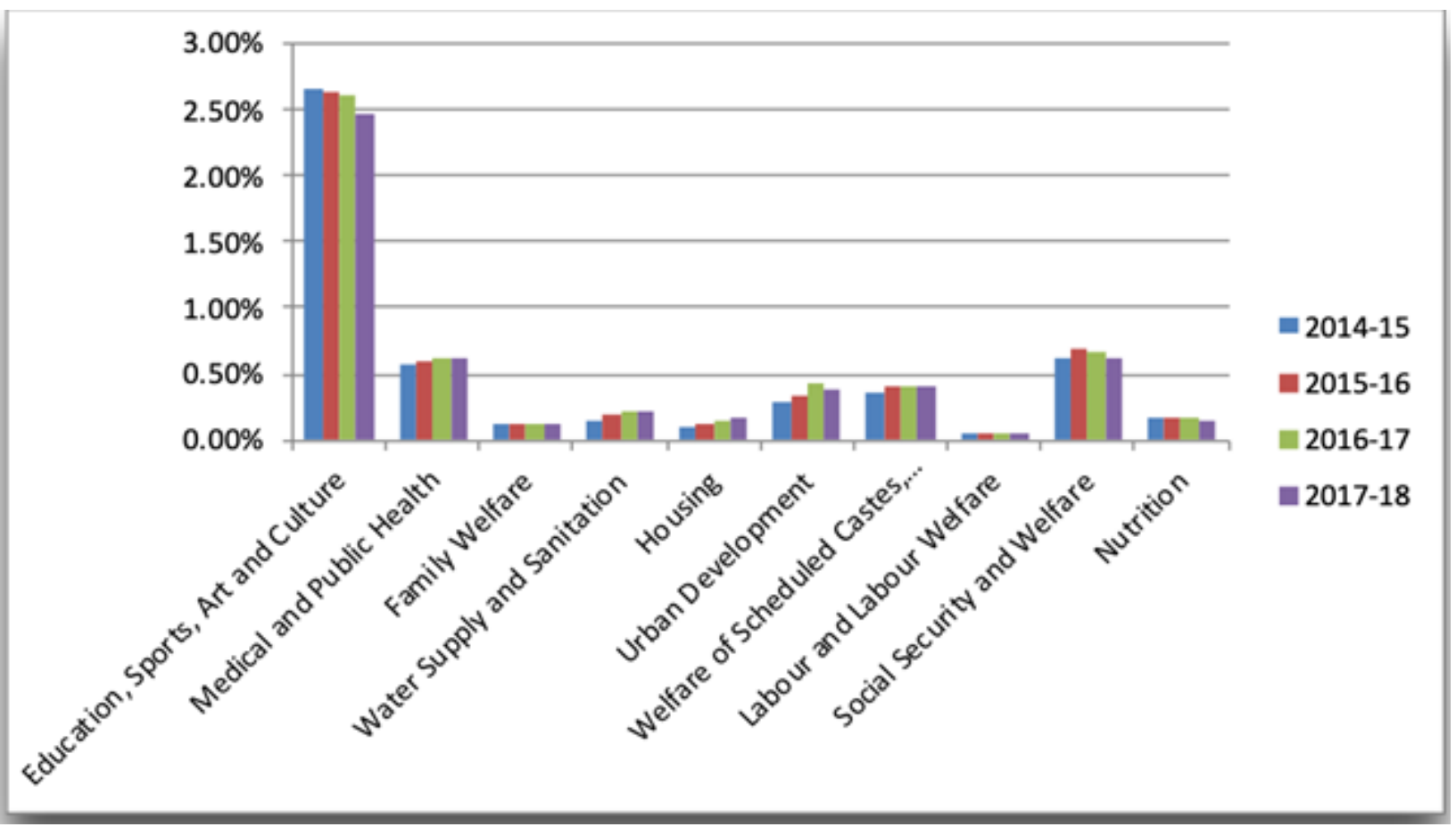

Source - Finance accounts of States; Auditor Comptroller General of India States Data

Table 1 :

\begin{tabular}{|c|c|c|c|c|}
\hline $\begin{array}{l}\text { Sum of Social } \\
\text { Service } \\
\text { Expenditure as a \% } \\
\text { of GSDP }\end{array}$ & 2014-15 & $2015-16$ & 2016-17 & 2017-18 \\
\hline Andhra Pradesh & $8.05 \%$ & $7.69 \%$ & $7.20 \%$ & $7.31 \%$ \\
\hline Assam & $9.24 \%$ & $7.78 \%$ & $8.91 \%$ & $7.41 \%$ \\
\hline Bihar & $9.25 \%$ & $9.67 \%$ & $9.65 \%$ & $9.44 \%$ \\
\hline Chhattisgarh & $6.96 \%$ & $7.19 \%$ & $8.38 \%$ & $8.58 \%$ \\
\hline Gujarat & $3.98 \%$ & $4.09 \%$ & $3.90 \%$ & $3.73 \%$ \\
\hline Haryana & $4.37 \%$ & $4.35 \%$ & $4.58 \%$ & $4.48 \%$ \\
\hline
\end{tabular}


International Journal of Social Science and Economic Research

ISSN: 2455-8834

Volume:05, Issue:10 "October 2020"

\begin{tabular}{|c|c|c|c|c|}
\hline Himachal Pradesh & $7.18 \%$ & $6.99 \%$ & $7.65 \%$ & $7.35 \%$ \\
\hline Jharkhand & $5.45 \%$ & $7.18 \%$ & $7.85 \%$ & $7.09 \%$ \\
\hline Karnataka & $4.31 \%$ & $4.43 \%$ & $4.51 \%$ & $4.34 \%$ \\
\hline Kerala & $4.63 \%$ & $4.91 \%$ & $5.32 \%$ & $5.12 \%$ \\
\hline Madhya Pradesh & $6.68 \%$ & $7.88 \%$ & $7.39 \%$ & $8.01 \%$ \\
\hline Maharashtra & $4.33 \%$ & $4.19 \%$ & $4.13 \%$ & $3.86 \%$ \\
\hline Odisha & $6.67 \%$ & $7.50 \%$ & $7.01 \%$ & $6.77 \%$ \\
\hline Punjab & $3.87 \%$ & $3.82 \%$ & $3.67 \%$ & $3.23 \%$ \\
\hline Rajasthan & $6.13 \%$ & $6.36 \%$ & $6.51 \%$ & $6.35 \%$ \\
\hline Tamil Nadu & $4.69 \%$ & $4.66 \%$ & $4.25 \%$ & $4.09 \%$ \\
\hline Telangana & $3.71 \%$ & $5.27 \%$ & $5.35 \%$ & $4.94 \%$ \\
\hline Uttar Pradesh & $6.02 \%$ & $7.25 \%$ & $7.36 \%$ & $6.12 \%$ \\
\hline West Bengal & $5.59 \%$ & $5.94 \%$ & $6.54 \%$ & $5.96 \%$ \\
\hline
\end{tabular}

Table 2 :

\begin{tabular}{|l|r|r|r|r|}
\hline $\begin{array}{l}\text { Sector wise Expenditure as a \% } \\
\text { of GSDP for all states }\end{array}$ & \multicolumn{2}{|c|}{$2014-15$} & $2016-17$ & $2017-18$ \\
\hline $\begin{array}{l}\text { Education, Sports, Art and } \\
\text { Culture }\end{array}$ & $2.65 \%$ & $2.63 \%$ & $2.60 \%$ & $2.47 \%$ \\
\hline Medical and Public Health & $0.58 \%$ & $0.60 \%$ & $0.61 \%$ & $0.63 \%$ \\
\hline Family Welfare & $0.13 \%$ & $0.13 \%$ & $0.12 \%$ & $0.13 \%$ \\
\hline
\end{tabular}


International Journal of Social Science and Economic Research

ISSN: 2455-8834

Volume:05, Issue:10 "October 2020"

\begin{tabular}{|l|r|r|r|r|}
\hline Water Supply and Sanitation & $0.16 \%$ & $0.19 \%$ & $0.23 \%$ & $0.22 \%$ \\
\hline Housing & $0.11 \%$ & $0.12 \%$ & $0.14 \%$ & $0.17 \%$ \\
\hline Urban Development & $0.30 \%$ & $0.33 \%$ & $0.43 \%$ & $0.37 \%$ \\
\hline $\begin{array}{l}\text { Welfare of Scheduled Castes, } \\
\text { Scheduled Tribes and Other } \\
\text { Backward Classes }\end{array}$ & $0.37 \%$ & $0.41 \%$ & $0.41 \%$ & $0.42 \%$ \\
\hline $\begin{array}{l}\text { Labour and Labour Welfare } \\
\text { Social Security and Welfare }\end{array}$ & $0.06 \%$ & $0.05 \%$ & $0.05 \%$ & $0.06 \%$ \\
\hline Nutrition & $0.61 \%$ & $0.69 \%$ & $0.67 \%$ & $0.61 \%$ \\
\hline
\end{tabular}

Furthermore, a state wise analysis of sectoral service expenditure gives further insight into the fact even though increased untied transfers to states allows states greater flexibility in expenditure, such that investments could reflect state specific priorities, they don't. We consider the examples of Himachal Pradesh and Chattisgarh to highlight the same (see Figure 8 in the appendix). The former has a high per capita incomeof Rs 1,83,140 (2018-19), and high literacy levels of $83.78 \%$ and low infant mortality rate of 35 per 1000 . Chhattisgarh, on the other hand, is much poorer with a per capita income of Rs. 96,887 (2018-19) with poorer performance on social indicators (literacy rate of $70.3 \%$ and infant mortality rate of ). Yet both states see a similar response to the changes in untied funds availability in all sectors except 'Medical and Public Health' and 'Water supply and Sanitation' (and both these states saw a huge spike in untied funds availability as is evident in the previous figures). Conceptually, increased untied transfers to states allows states greater flexibility in expenditure, such that investments could reflect state specific priorities. Thus, it would be reasonable to expect shifts in expenditure across sectors but this does not seem to be the case. Data for Bihar is also shown in Figure 8 in the appendix ; Bihar a further lower income country and has a much lower literacy rate of around $63 \%$ and the trends shown by it is similar to that of the other two states (largely a status quo has been maintained ). It is also important to note that Bihar has the largest value of Untied funds as a \% of GSDP and did see a big spike post 2014-15.

\section{Debunking the centralisation vs decentralisation tug of war (DISCUSSION)}




\section{International Journal of Social Science and Economic Research}

ISSN: $2455-8834$

Volume:05, Issue:10 "October 2020"

As far as social policy/sector investments in India are concerned, the post FFC budgets can be explained using the idea of systemic inertia in financial social policy. As is highlighted in the analysis in the paper, the FFC recommendations gave states greater access to untied resources by altering the overall structure of financing available to states. Theoretically this should have had resulted in some upward or downward shit in budget allocation for social sector investments, however this has not been observed so far. The data and our analysis clearly indicates status quo in the states respective budget patterns. The analysis thus points towards a lack of interest and preparedness at the state levels on how to utilise the opportunity of greater access to untied funds for changing patterns of social sector investments. Rather than welcome the recommendations of the FFC, almost immediately after the 2015 Union budget was tabled, the rhetoric at the state level shifted to the cuts in CSS's and changes in the fund-share pattern. For instance, the Karnataka state finance minister during his budget speech said, "The Central Government gave the impression.... that States would be getting a huge financial largesse.... However, our happiness was short-lived.... what has been given by the Central Government on the one hand has been taken away by the other hand."

In a similar vein, the Chief Minister of Odisha accused the Union government of "step-motherly treatment 'stating, Odisha has been hit on two counts - unfavourable recommendations of 14th Finance Commission and lesser plan allocation in Budget.The Chief Minister of the state of Andhra Pradesh went on record to state, 'The reduction of the Central share for key schemes...will have adverse effect on the State development indicators'. The Chief Minister of Bihar was similarly critical, stating, '(The) 14th Finance Commission has done more harm than good to the State. As per the recommendations of 14th Finance Commission, there is a reduction in the resources of the State...'. Concerns were also raised by social activists and policy commentators on the implications of the cuts in CSSs on social policy in India, arguing that this is likely to result in a significant drop in social policy investments in state. All of these criticism however failed to account for the fact that what the states "lost on one hand" (which was cuts in CSS) they gained via share in central taxes. Thus the total allocation of funds never really reduced. All that the such ministers and bureaucrats made evident was that they themselves were certain that the state did not have the required capability to use the untied transfers for social sector expenditure and needed some control (orcentralisation ) in this regard. Thus, in what appears to be a direct contradiction of the demands for greater flexibility, many state officials argued that "state level planning capacity is weak and therefore, it is far easier to invest in social sectors through CSSs because they come with clear guidelines and rules".

What emerges from this analysis of state budgets is a near consensus in favour of the status quo which is a centralised rather than decentralised financing architecture for social sectors. This consensus is indeed puzzling when one takes into consideration the fact that the FFC 


\section{International Journal of Social Science and Economic Research}

ISSN: $2455-8834$

Volume:05, Issue:10 "October 2020"

recommendations were formulated as a direct response to demands from states ! By convention (and design) all Finance Commissions conduct a detailed set of dialogues with state governments. In these interactions, the FFC report notes a marked preference for formula-based predictable fund transfers through devolution of taxes. The report states that almost all state governments raised concerns over the growing trend of attaching conditionalities to grants, which made spending difficult. Some states also argued that the conditions-linked, discretionary transfers violated the principle of state autonomy. States were particularly vocal in their preference for reducing CSS. According to the FFC, States have, suggested that the funds transferred by the Union Government for expenditure on State subjects through various CSS should be subsumed under the funds transferred through vertical devolution. The States have emphasised that there is a need to enhance the existing level of formula-based fiscal transfers.

In other words it is very likely that for a country like India, when corruption is rampant and deep rooted at all levels of the political structure (be it at the ministry or at the panchayats) expenditure efficiency and local accountability is incredibly poor. Thus perhaps having a central umbrella to ensure social sector funding could be more optimal than leaving it to the states to allocate funds as per there own priorities (which would have been a more optimal outcome had the our system been more ideal in terms of efficacy and absence of corruption).

\section{Conclusion}

This paper has traced the primary reasons behind the FFC reform which targeted an increase in untied funds and whether the same has been a success. Success is then gauged at two levels, implementation and outcome. At the level of implementation wherein we see that the flow of untied funds did greatly increase across states, compensated by a simultaneous decrease in tied funds. At the level of outcome however, states do not seem to have achieved any benefit out of the changed fiscal structure which provides them greater flexibility in terms of expenditure allocation for the revenue receipts that they receive from the centre; the states have largely maintained status quo.

We discussed several reasons for this tendency to maintain status quo. To sum them up, the culture of centralisation within the bureaucracy coupled with the lack of political incentives for fiscal decentralisation at state level are the major reasons behind this anaemic condition. States governments have been two-faced by criticising the recommendations which they themselves supported; this is a simple strategy to shift blame on others for ones one shortcomings and the Indian political system is emblematic of the same.

\section{References}


International Journal of Social Science and Economic Research

ISSN: 2455-8834

Volume:05, Issue:10 "October 2020"

Aiyar, Y., and M. Walton. 2015. Rights, Accountability and Citizenship: Examining India's Emerging Welfare State. In Governance in Developing Asia: Public Service Delivery and Empowerment, edited by A. B. Deolalikar. Edward Elgar Publishing.

Priyam, M. 2015. Contested Politics of Educational Reform in India: Aligning Opportunities with Interests.. Oxford: Oxford University Press.

Tillin, L. 2017. India's Democracy at 70: The Federalist Compromise. Journal of Democracy, 28: $64-75$.

Stepan, A. 1999. Federalism and Democracy: Beyond the US Model. Journal of Democracy 10 (4): 19-34.

Wheare, K. 1964. Federal Government. New York: Oxford University Press.

Rao, G., and N. Singh. 2005. Political Economy of Federalism in India. OxfordUniversity Press.

Mitra, S. K., and M. Pehl. 2010. Federalism. In The Oxford Companion to Politics in India, edited by N. G. Jayal, and P. B. Mehta, 43-60, Oxford University Press.

Saez, L. 2002. Federalism Without a Centre: The Impact of Political and Economic Reform on India's Federal System. Sage.

Singh, M. P., and D. V. Verney. 2003. Challenges to India's Centralised Parliamentary Federalism. Publius: Journal of Federalism 33 (4): 1-20.

Srinivasan, T. N., and J. S. Wallack. 2011. Inelastic Institutions: Political Change and Inter governmental Transfer Oversight in Post-Independence India. India PolicyForum 7 (1): 203251.

\section{Appendix}

Figure 1. 


\section{International Journal of Social Science and Economic Research}

ISSN: $2455-8834$

Volume:05, Issue:10 "October 2020"

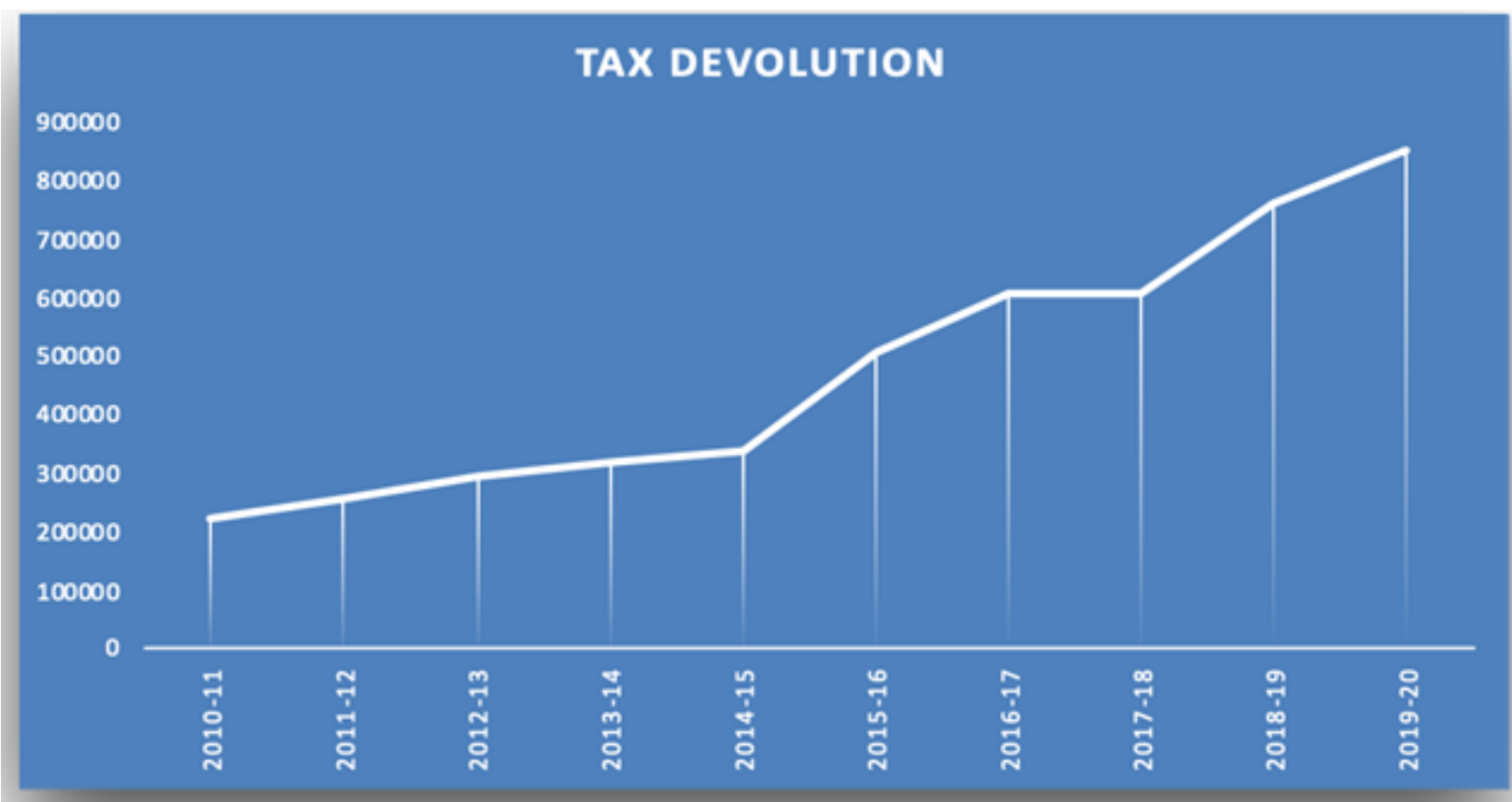

Source - e-states Database ; RBI Handbook of Statistics

Figure 2. 


\section{International Journal of Social Science and Economic Research}

ISSN: $2455-8834$

Volume:05, Issue:10 "October 2020"

\section{TAX DEVOLUTON FROM CENTRE TO STATES AS \% OF GDP}

\section{9-20}

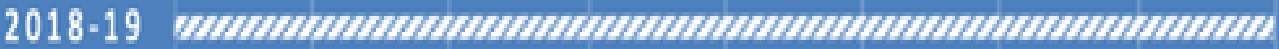

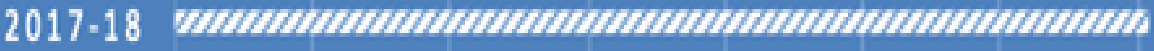

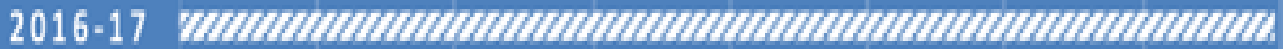

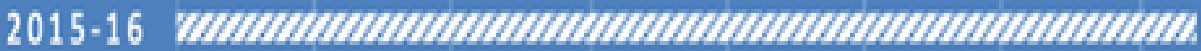

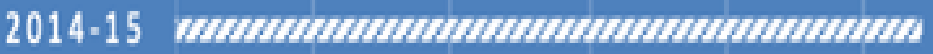

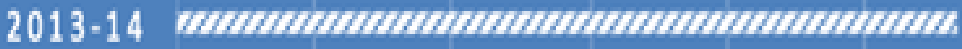

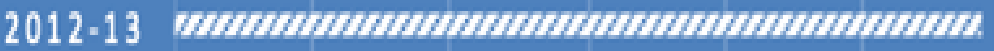

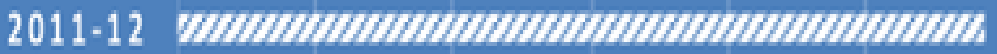

2010-11 WDInس

$\begin{array}{llllllllll}0.00 \% & 0.50 \% & 1.00 \% & 1.50 \% & 2.00 \% & 2.50 \% & 3.00 \% & 3.50 \% & 4.00 \% & 4.50 \%\end{array}$

Source - $\theta$-states Database ; RBI Handbook of Statistics

Figure 3. 
International Journal of Social Science and Economic Research

ISSN: 2455-8834

Volume:05, Issue:10 "October 2020"

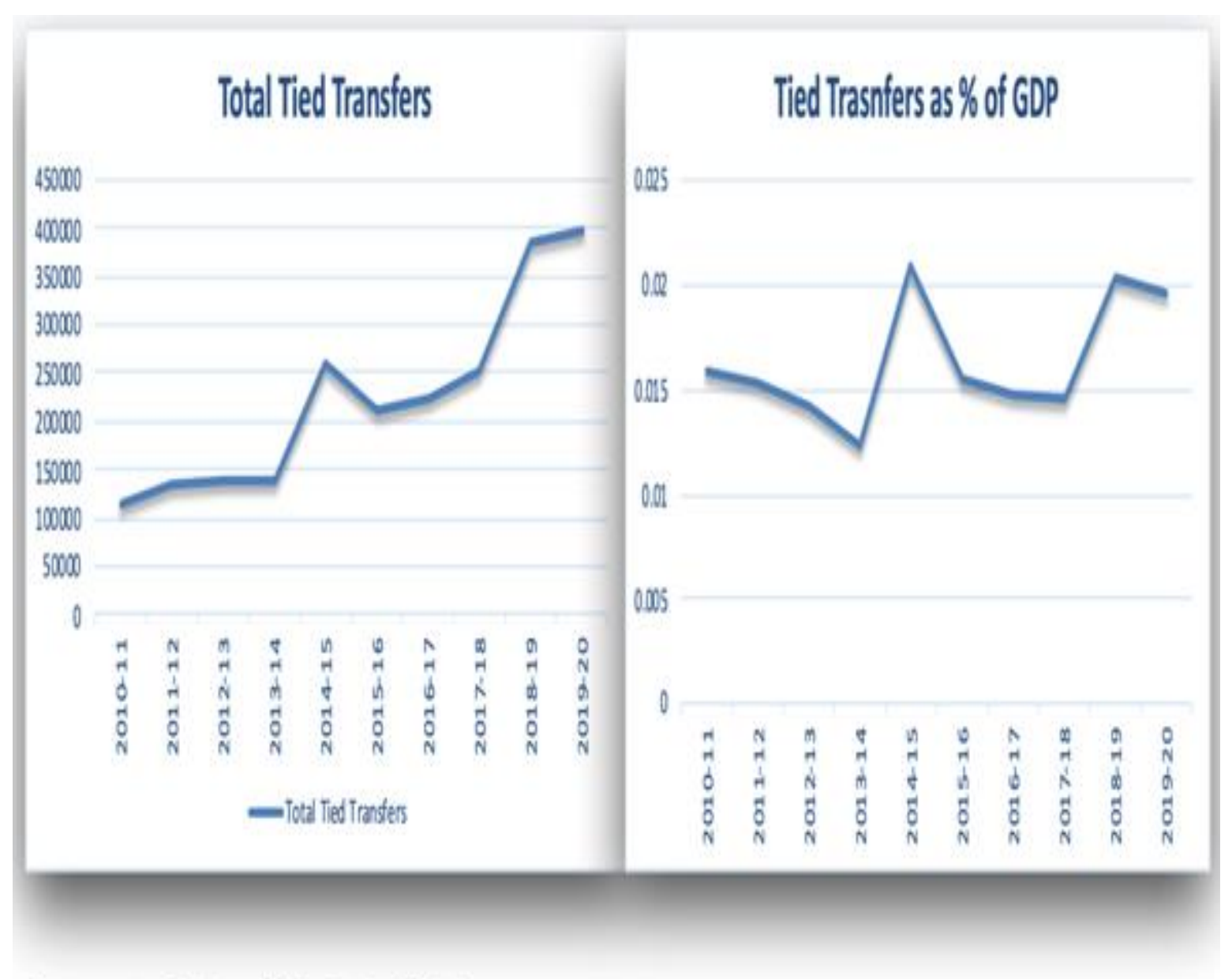

Source - e-states Database ; RBI Handbook of Statistics

Figure 4. 


\section{Total Funds from Centre to States as a \% of GDP}

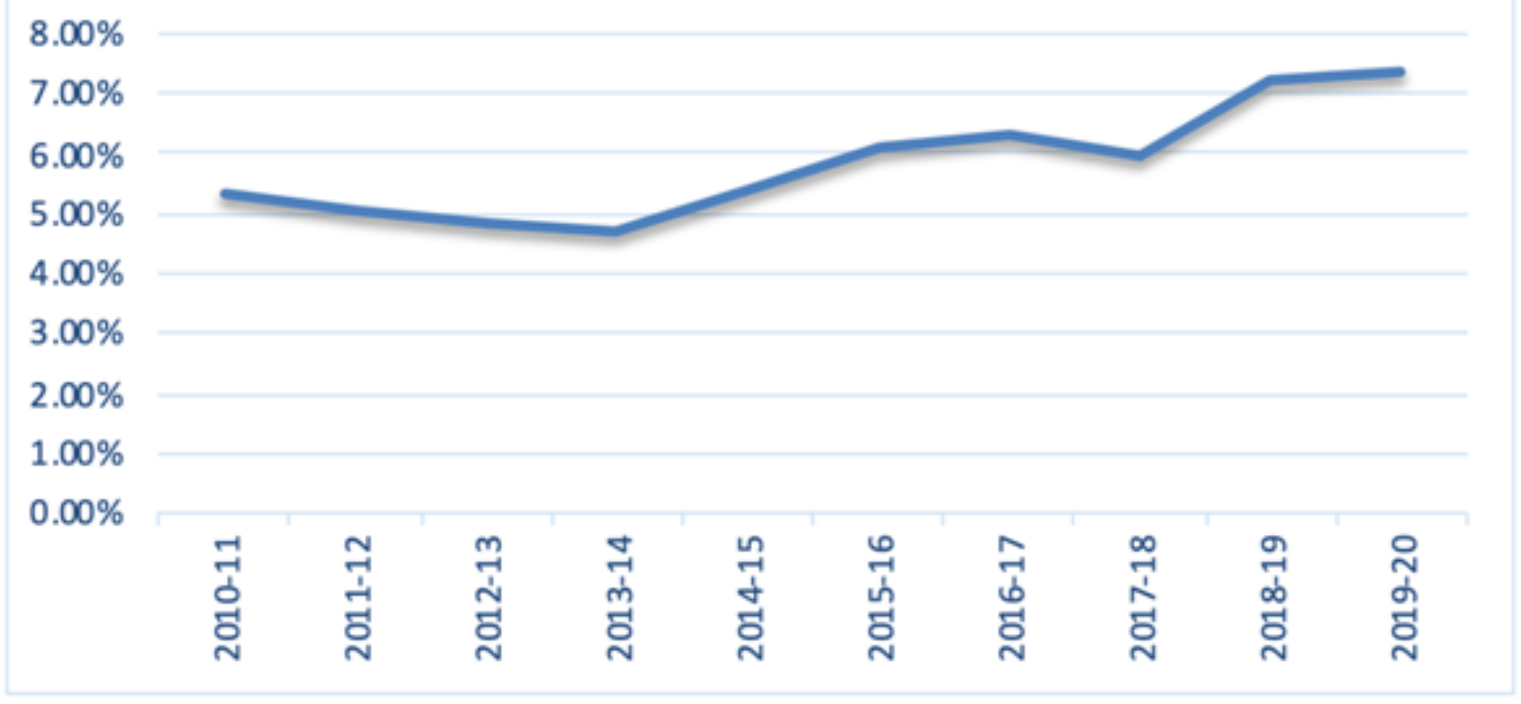

Figure 5.

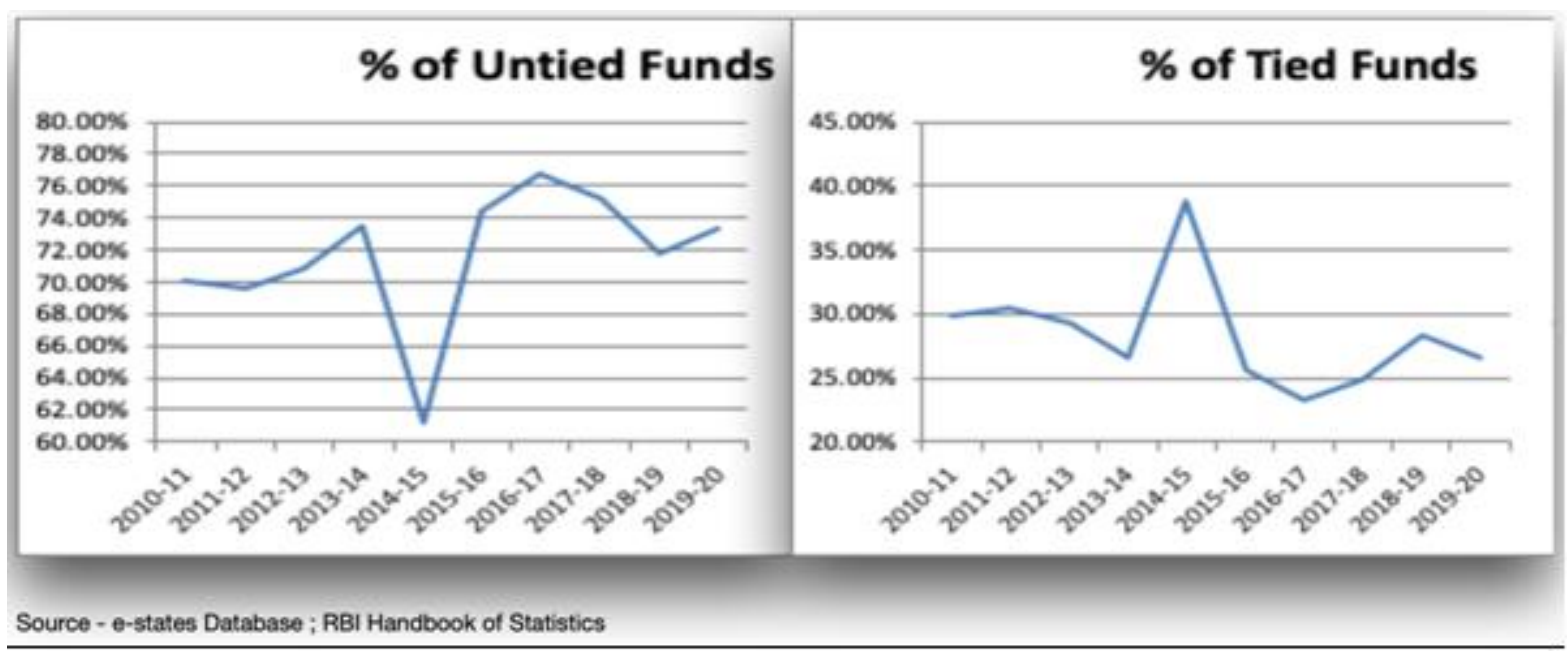

Figure 8. 
International Journal of Social Science and Economic Research

ISSN: 2455-8834

Volume:05, Issue:10 "October 2020"

Sector wise Expenditure as a \% of GSDP for Chattisgarh and Himachal Pradesh in India :

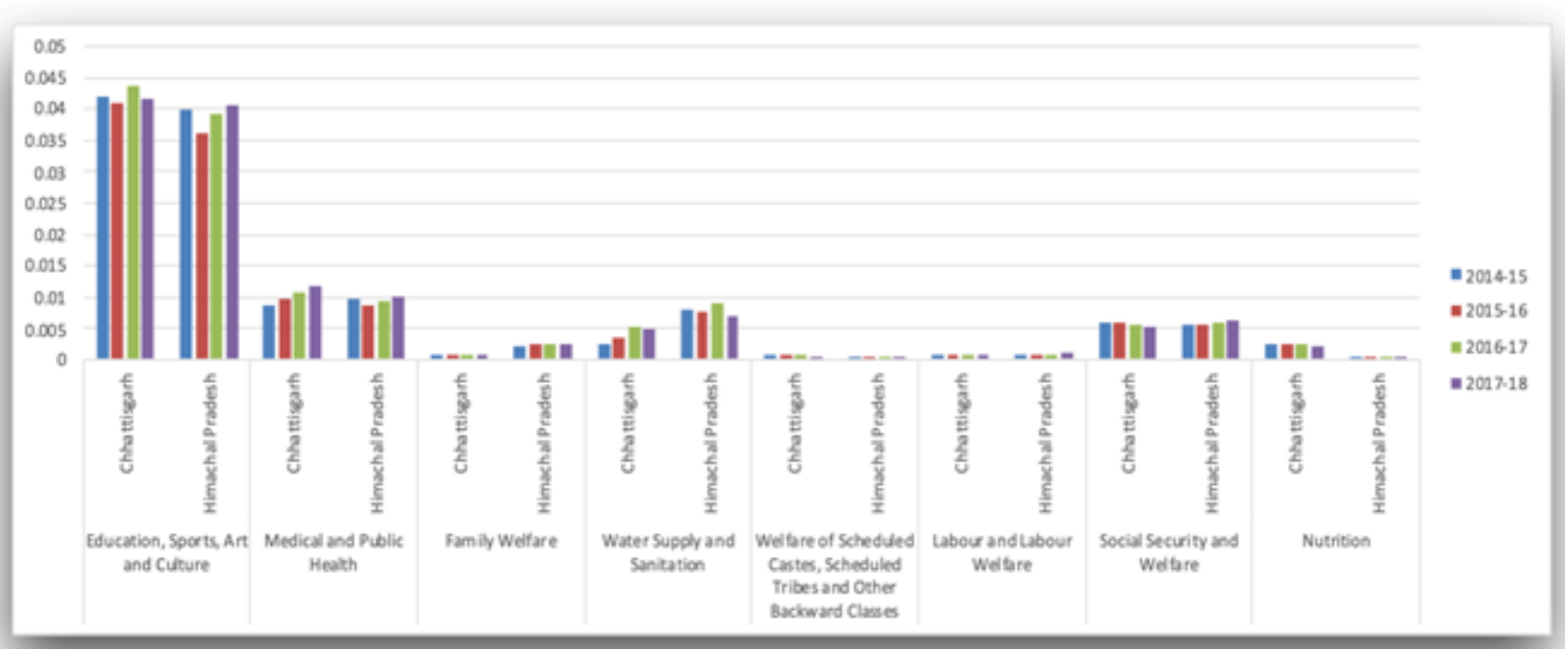

Sector wise Expenditure as a \% of GSDP for Bihar :

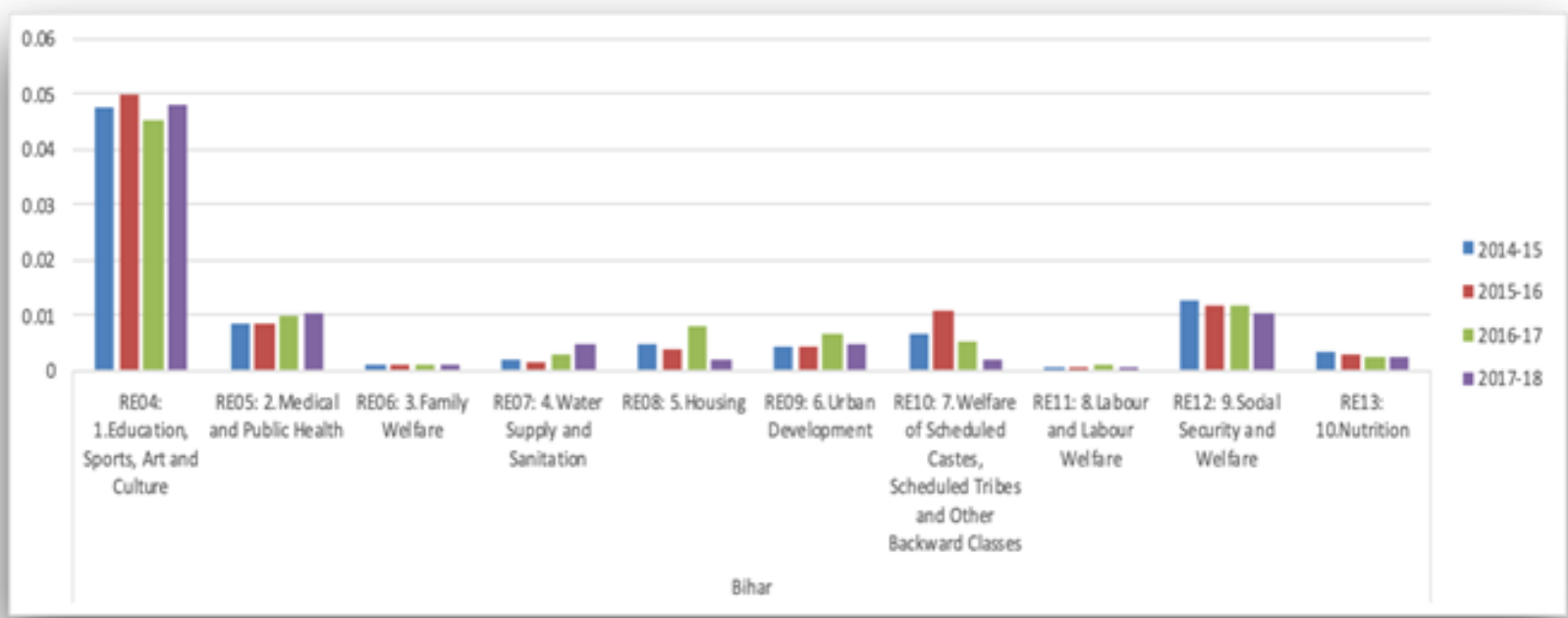

Source - Finance accounts of States; Auditor Comptroller General of India States Data 